\title{
ANALYSIS OF NEED FOR DEVELOPMENT OF HOTS-BASED MATHEMATICS TEACHING MATERIAL IN ELEMENTARY SCHOOLS
}

\author{
Vivi Astuti Nurlaily ${ }^{1}$, Husna Imro'athush Sholihah ${ }^{2}$ \\ ${ }^{1}$ STKIP Muhammadiyah Blora \\ ${ }^{2}$ STKIP Muhammadiyah Blora \\ ${ }^{1}$ viviastutinurlaily@gmail.com, ${ }^{2}$ husna.azka@gmail.com
}

\begin{abstract}
One of the 2013 curriculum transformation elements in elementary schools is strengthening the learning process and familiarizing the development of higher-order thinking skills (HOTS) for students. This needs to be supported by teaching materials to support HOTS-based learning.This research aims to analyze the need for HOTS-based mathematics teaching materials in elementary schools. This research uses a descriptive approach. The subjects of this research were fourth-grade students of public elentary school in Tunjungan Blora area. The data collected in this research uses observation sheets, interviews, and document studies. Observations and interviews were carried out to teachers and fourth-grade students. Otherwise, the document studies were carried out on learning resources used in mathematics learning. The validity test data was conducted by using triangulation techniques. The results showed that: first, the characteristics of mathematics teaching materials used in elementary schools of Blora Regency have not described the HOTS material. Second, the need for teachers shows that the problems faced by teachers in learning mathematics have limited learning resources. Third, the student's need toward teaching material products is shown by the low interest of students in learning mathematics. Fourth, students have not been invited to think critically in learning mathematics.
\end{abstract}

Keywords: Elementary School, HOTS, Mathematics, Teaching Material.

\begin{abstract}
Abstrak
Salah satu elemen transformasi kurikulum 2013 di sekolah dasar adalah penguatan proses pembelajaran dan pembiasaan pengembangan keterampilan berpikir tingkat tinggi (HOTS) bagi siswa. Hal itu perlu didukung sebuah bahan ajar untuk menunjang pembelajaran berbasis HOTS. Penelitian ini bertujuan untuk menganalisis kebutuhan bahan ajar matematika berbasis HOTS di sekolah dasar. Penelitian ini menggunakan pendekatan deskriptif. Subjek penelitian ini adalah siswa kelas IV SD Negeri di daerah Tunjungan Blora. Data yang dikumpulkan dalam penelitian ini menggunakan lembar observasi, wawancara, dan studi dokumen. Observasi dan wawancara dilakukan kepada guru dan siswa kelas empat. Sedangkan studi dokumen dilakukan terhadap sumber belajar yang digunakan dalam pembelajaran matematika. Uji validitas data dilakukan dengan menggunakan teknik triangulasi. Hasil penelitian menunjukkan bahwa: pertama, karakteristik bahan ajar matematika yang digunakan di SD Kabupaten Blora belum mendeskripsikan materi HOTS. Kedua, kebutuhan guru menunjukkan bahwa permasalahan yang dihadapi guru dalam pembelajaran matematika memiliki keterbatasan sumber belajar. Ketiga, kebutuhan siswa terhadap produk bahan ajar ditunjukkan dengan rendahnya minat siswa dalam belajar matematika. Keempat, siswa belum diajak berpikir kritis dalam pembelajaran matematika.
\end{abstract}

Kata Kunci: Bahan Ajar, HOTS, Matematika, Sekolah Dasar.

\section{INTRODUCTION}

Teaching materials are one of the components that play an important role in the learning process. The use of teaching materials as a learning resource aims to facilitate the preparation and delivery of learning materials used by teachers to achieve learning objectives. According 
to Samuel (2009) the use of instructional materials in teaching/learning process exposes the learner to primary experiences and this enriches learning. Prastowo (2013) explained that teaching materials are all materials (both information, tools, and texts) that are arranged systematically, which the full figure of competencies that will be mastered by learners and used in the learning process with the aim of planning and studying the implementation of learning.

The content of the subject matter contained in the teaching material can be distinguished into four, namely: facts, concepts, procedures and principles. Facts are the nature of symptoms, objects or events whose form can be captured by the senses. Facts are simple subject matter because they only remember specifics. Concepts are all things in the form of new understandings that can arise as a result of thought, including definitions, understandings, special characteristics, nature, core, and so on (Prastowo, 2013). A procedure is a subject matter related to a student's ability to systematically explain steps about something. The relationship between two or more empirically tested concepts is called generalization which can then be drawn into principle (Sanjaya, 2008).

The main purpose of the preparation of teaching materials is to activate students during the learning process that suits the needs of the school, the residence and the needs of the students. Teaching materials can also facilitate teachers in the process of presenting learning materials that will be given in the classroom. The Ministry of National Education (Departemen Pendidikan Nasional, 2013) argues that teaching materials have several characteristics, namely self-instructional, self-contained, stand-alone, adaptive, and user friendly. Teaching materials have various types, some are printed and non-printed. Printed teaching materials that are often found include handouts, books, modules, brochures, and student worksheets.

Problems related to mathematics are still the main problems that occur in the world of education. The results OECD (2018) showed that Indonesian students' ability in mathematics achieved an average score of 379 with an OECD average score of 487. It makes Indonesia ranked 72 out of 78 PISA participating countries. The low math ability of students is influenced by several factors, one of which is the condition of the teaching material. The problems in question are quite diverse ranging from low student learning interest, lack of motivation to learn mathematics, low math learning achievement, low ability to understand math concepts, problem solving ability. This is due to many factors such as students' disinterest in mathematics, the way teachers convey inappropriate materials, the methods used are not yet appropriate, learning resources are less supportive, and other causes. 
One element of the changes in the 2013 curriculum at the elementary school level is the strengthening of the learning process. Through strengthening the learning process is expected to improve the quality of learning more effectively, efficiently, fun, and meaningful, so as to improve the quality of achievement of learning outcomes and put forward students critical thinking (not just conveying factual). Teachers must be able to develop and convert from lower order thinking skills (LOTS) to Higher Order Thinking Skills (HOTS).

Higher Order Thinking Skills is a process of thinking of learners at a higher cognitive level developed from a variety of cognitive concepts and methods and learning taxonomy such as problem solving methods, bloom taxonomy, and taxonomy of learning, teaching, and assessment (Saputra, 2016). Higher order thinking skills include problem solving skills, creative thinking ability, critical thinking, argumenting ability, and decision making ability.

According to Newman and Wehlage (Widodo, 2013) with higher order thinking learners will be able to distinguish ideas or ideas clearly, argue well, be able to solve problems, be able to construct explanations, be able to hypothesize and understand complex things more clearly. According to Vui (Kurniati, 2014) higher order thinking skills will occur when someone associates new information with information that has been stored in his memory and/or reorganizes and develops the 10 information to achieve a goal or find a solution to a difficult situation to solve. The main purpose of higher order thinking skills is how to improve the thinking ability of learners at a higher level, especially with regard to the ability to think critically in receiving various types of information, creative thinking in solving problems using their knowledge and making decisions in complex situations (Saputra, 2016).

National Centre for Competency Training (2007) in Prastowo (2013) explained "teaching materials are all forms of materials used to help teachers or instructors in carrying out the learning process in the classroom, the material can be either written or unwritten materials". When the goal is learning that leads to high-level thinking skills then it is necessary to arrange teaching materials that are hots charged. Meanwhile, Pratiwi (2018) explained that hots teaching materials proved effective in improving students' learning outcomes in the study results Glazed in the results of the study HOTS teaching materials are one of the alternatives to teach learners to be able to develop high-level thinking skills.

\section{METHOD}

This research uses a descriptive approach. Gay, Mills, \& Airasian, (2012) said that descriptive research determines and describes the things are. This study describes the analysis 
of the needs of math teaching materials in elementary school. The subject of the study was a grade 4 teacher at publick elementary school in the Tunjungan Subdistrict, Blora. Data collection in this study using observation sheets, interviews, and document studies. Observations and interviews were conducted to teachers and students in grade IV elementary school. Observation is a method of observing the learning process of natural and artificial environmental social sciences by applying problem-based learning models observed by researchers. Interviews are methods used to obtain data by conducting oral question and answer processes between researchers as interviewers to students and classroom teachers as informants. Interviews are conducted individually with each informant and interviewed directly by researchers in depth, free, clear and without any interference from others. In addition, document studies are conducted on learning resources used in mathematics learning. Data validity check according to Sugiyono (2015) is one way to account for the accuracy of the data obtained. Data validity test is done using triangulation technique. Triangulation of data collection techniques is carried out to test the credibility of data done by checking the same data source with different techniques. After the data needed in this research is collected, then the organization and systematization of the data before being used as analysis material. Triangulation techniques used in this research are interviews, document analysis and observation. The data analysis techniques used are interactive analysis of Miles and Huberman models (Soegiyono, 2015) through data collection, data reduction, data presentation, and data verification. The results of the analysis of the research data were presented using qualitative descriptive with narrative text for the needs of HOTS-based mathematics teaching materials in elementary schools.

\section{RESULTS AND DISCUSSION}

Based on observations during mathematics learning, data are obtained as stated in table 1. Learning observations.

Table 1. Learning Observation Results

\begin{tabular}{ll} 
No. & Observation Results \\
\hline 1. & Students' low interest in math learning
\end{tabular}




\begin{tabular}{cl}
\hline 2. & $\begin{array}{l}\text { Learning resources used by students and teachers in } \\
\text { learning are still very limited } \\
\text { Most students are not very active in the learning process } \\
\text { and still tend to be passive }\end{array}$ \\
4. & There are some students who talk to their friends during \\
the learning process
\end{tabular}

The observations showed that the math teaching materials used by the school were books from the government. During the lesson, the teacher is only fixated on the material listed in the teaching book used. Judging from the learning methods used by teachers, classroom learning is still dominated by lectures and question and answer activities. In addition, the activities carried out by students during the learning process focus on individual work such as working on evaluation questions provided by teachers. Therefore, students become less interested and easily bored with learning. This is supported by Mutholib's opinion (2017) which states that teachers are an important factor in the implementation of the curriculum. Therefore, the way teachers teach related to the use of teaching books that are not maximal in mathematics learning will affect students' understanding. So teachers need to make learning planning by paying attention to learning resources and teaching materials that can be used so that learning can be carried out to the maximum to achieve learning goals.

The following data of the results of interviews with teachers are shown in table 2 . The results of the teacher's interview.

Table 2. Teachers interview results 

Teacher's experience in
teaching mathematics grade IV

Curriculum used in schools and

2. barriers experienced by teachers during this time

Types of mathematical

3. teaching materials that have been used

\section{Assumptions}

4. existing/used mathematical teaching materials

Student response to teaching

5. materials that currently exist/are used

6. Advantages of existing/used math teaching books

7. Lack of existing/used math textbooks

Implementation

8. mathematics learning in schools

9. Obstacles in mathematics learning activities

10. Factors that cause the
occurrence of such obstacles

11. Evaluation of math defense applied by teachers
Using the lecture method by providing material explanations to students sourced from books and sheets.

The curriculum that is used in grade IV is the 2013 curriculum. Obstacles in the application of this curriculum to the assessment of learning.

Books used in mathematics learning are books from the government and books sheets.

The material is not very broad and does not cause students curiosity. In addition, if from lks the material displayed is less interesting because it is not colored.

Students get bored quickly because the books used have not provided guidelines for activities or activities that students can do to make them happy.

The existing book is simple and does not complicate its application.

The material is not extensive and only a little practice problem.

of Learning with lecture methods and students easily bored and sleepy at the time of learning.

Students are not interested, speak for themselves, curiosity is low, learning resources are limited, supporting teaching materials do not yet exist.

Learning is dominated by teachers, teachers only use government-sourced resources and teaching materials.

Practice, daily replays.

Interviews at this stage aim to gather information about the condition of mathematics teaching materials and the need for HOTS-based math teaching materials in the field. Based on the results of the interview obtained the following data: the learning resources used by teachers at the time of mathematics learning are still limited to teacher books and student books obtained from the government, the math material contained is still very limited, students' math scores are lower compared to other subjects, most students still have difficulty learning math materials, teachers have never used HOTS learning in mathematics, after the teacher learns about HOTS-based learning, the teacher argues the need to develop the learning to improve students' ability to think critically and creatively and be able to solve problems. 
Based on the results of the interview that has been conducted in accordance with the theory of Higher Order Thinking Skills is a thought process of learners at a higher cognitive level developed from various concepts and methods of cognitive and taxonomy of learning such as problem solving methods, bloom taxonomy, and taxonomy of learning, teaching, and assessment (Saputra, 2016:91). Higher order thinking skills include problem solving skills, creative thinking ability, critical thinking, argumenting ability, and decision making ability.

In table 3. Presented the results of document studies conducted in mathematics learning grade IV.

Table 3. Document Study Results

\begin{tabular}{|c|c|c|}
\hline No. & Indicators & Document study results \\
\hline 1. & Syllabus & There is a syllabus document. \\
\hline 2. & RPP & There are RPP documents although incomplete. \\
\hline 3. & Learning Media & $\begin{array}{l}\text { The media used is still limited, utilizing objects in the } \\
\text { classroom and around the students. }\end{array}$ \\
\hline 4. & Evaluation Tool & $\begin{array}{l}\text { For daily activities teachers use the questions in the book, for } \\
\text { daily replays teachers make questions independently, and in } \\
\text { midterm and final semester assessment teachers use } \\
\text { questions from the government. }\end{array}$ \\
\hline 5. & $\begin{array}{l}\text { Teaching } \\
\text { Materials }\end{array}$ & $\begin{array}{l}\text { Teaching materials used are still limited, there is no other } \\
\text { supporting teaching material other than government books, } \\
\text { the characteristics of mathematical teaching materials used } \\
\text { have not elaborated the material that is HOTS. }\end{array}$ \\
\hline 6. & $\begin{array}{l}\text { Assessment } \\
\text { document }\end{array}$ & The teacher has recapitulated the student's grades. \\
\hline
\end{tabular}

Document analysis is carried out to find out the content and scope of materials contained in learning resources that have been used by teachers and students in mathematics learning so far. The learning resources analyzed were curriculum books 2013.

The results of the document analysis are as follows: the 2013 curriculum has used a scientific approach, so that there are already substances that invite students to be more active, the math material contained in the teaching book is still limited and not yet in-depth. Judging from the teacher's book and student book, the demonstrations and questions contained are still few and limited, so the students' thinking activities are still not optimal. This is a guideline on the need for teaching materials to support the learning process. According to Sunendar (2008) that teaching materials have several roles, among others: 1) reflect a sharp and innovative point of view on teaching and demonstrate its application in teaching materials presented;2) present 
a source of problem that is rich, easy to read and varies according to the interests and needs of learners; 3) provide a neatly arranged and gradual source; 4) presenting teaching methods and means to motivate learners; 5) to support practical exercises and tasks; 6) presents materials / means of evaluation and remedial that are harmonious and appropriate.

Prastowo (2013) explained that the manufacture of teaching materials includes four main things, namely: 1) helping students in learning something, 2) providing various types of teaching materials options, thus preventing the onset of boredom in students, 3) making it easier for students to carry out learning, 4) to make learning activities more interesting. The usefulness of teaching materials is actually inseparable from the purpose so that learning becomes more meaningful. Effective teaching materials should be able to help students to perform certain activities so that students can master the learning objectives.

Based on the results of the analysis above, which is derived from observations, interviews, and document studies, it can be concluded that the use of mathematics teaching materials in the classroom is still limited to books derived from the government. The teaching materials actually have substances that invite students to be more active, using a scientific approach so that there are $5 \mathrm{M}$ activities in them. However, the mathematical material contained in the teaching material is still limited and not yet in-depth. The math material listed in the book is only limited to the delivery of concepts and there have been no activities that spur critical thinking skills and problem solving for students. The methods used by teachers are still limited to lectures and question and answer questions, so students' learning outcomes are still relatively low. Based on these results, there needs to be development of HOTS-based math teaching materials that are able to attract students so as to encourage students to be more active during learning and able to encourage students to think critically.

\section{CONCLUSION}

Based on the results of the analysis of the data that has been described can be concluded, namely the results of the study showed that: first, the characteristics of mathematics teaching materials used in elementary schools in Blora district have not described hots material. Second, the needs of teachers show that the problems faced by teachers in mathematics learning are limited in learning resources. Third, students' need for teaching materials products is indicated by the low interest of students to learn mathematics. Fourth, students have not been invited to think critically in math learning. This study is part of the initial study of the development of HOTS-based math teaching materials in elementary schools. The results of this research are 
expected to be an evaluation material of various parties in organizing mathematics learning in elementary schools. This research is also expected to be a study material for other researchers in analyzing and developing HOTS-based math teaching materials in future learning.

\section{ACKNOWLEDGMENTS}

The researcher would like to thank all those who have supported the research and preparation of the article. Research can take place because of the help of several contributing parties, namely teachers and students from the schools used in the research sample, as well as university leaders who always provide support and enthusiasm for completing research.

\section{REFERENCES}

Departemen Pendidikan Nasional. (2013). Dokumen kurikulum 2013. Depdiknas.

Depdiknas. (2008). Kurikulum Tingkat Satuan pendidikan. Depdiknas.

Gay, L. ., Mills, G. E., \& Airasian, P. (2012). EDUCATIONAL RESEARCH: Competencies for Analysis and Applications.

Kurniati, D., Harimukti, R., \& Jamil, N. A. (2016). Kemampuan berpikir tingkat tinggi siswa SMP di Kabupaten Jember dalam menyelesaikan soal berstandar PISA. Jurnal Penelitian Dan Evaluasi Pendidikan, 20(2), 142-155. https://doi.org/10.21831/pep.v20i2.8058

Mutholib, A. A., Sujadi, I., \& Subanti, S. (2017). Mathematics teachers' beliefs about scientific approach (SA) and implementation in mathematics learning. AIP Conference Proceedings, 1868(August). https://doi.org/10.1063/1.4995163

OECD. (2018). PISA 2018 Result: What Students Know and Can DO-Student Performance in Reading, Mathematics and Science. OECD-PISA.

Prastowo, A. (2013). Panduan Kreatif Membuat Bahan Ajar Inovatif. Diva Press.

Pratiwi, W., \& Alimuddin, J. (2018). Pengembangan bahan ajar bermuatan High Order Thinking Skill ( HOTS ) pada pembelajaran tema persatuan dalam perbedaan. Prosiding Seminar Nasional Unimus, 1, 531-538.

Samuel, A. W. (2009). The Importance of Instructional Materials In Our Schools an Overview. Researchgate, 2(March), 61-63.

Sanjaya, W. (2008). Perencanaan dan Desain Sistem Pembelajaran, Bandung: Kencana. Kencana Prenada Media Group.

Saputra, H. (2016). No TitlePengembangan Mutu Pendidikan Menuju Era Global: Penguatan Mutu Pembelajaran dengan Penerapan HOTS (High Order Thinking Skills. SMILE's Publishing. 
Sugiyono. (2015). Metode Penelitian Pendidikan: Pendekatan Kuantitatif, Kualitatif, dan $R \& D$. Alfabeta.

Sunendar, D. (2008). Strategi Pembelajaran. Remaja Rosdakarya.

Widodo, T., \& Kadarwati, S. (2013). To Improve Learning Achievement. Cakrawala Pendidikan, 32(1), 161-171. 